\title{
Peran Iman dalam Pengembangan Pribadi Konselor yang Efektif
}

\author{
Anwar Sutoyo \\ Program Studi Bimbingan dan Konseling, FIP, Universitas Negeri Semarang \\ email: anwarsutoyo@mail.unnes.ac.id
}

\begin{abstract}
Abstrak: Keberhasilan konseling bukan hanya ditentukan oleh pengetahuan dan ketrampilan yang dimiliki konselor, tetapi karakteristik pribadi menjadi determinan yang paling kuat dalam konseling (Corey, G, 2009:18). Konseling bukan sekedar apa yang diucapkan konselor, tetapi lebih dari itu adalah apa yang dilakukan konselor dalam kehidupan sehari-hari. Karakteristik pribadi tercermin dalam keikhlasan, ketulusan, kehangatan, dan sikap yang menyenangkan dalam memberikan layanan kepada konseli. Karakteristik tersebut akan lebih kokoh manakala dilandasi dengan iman yang benar dan kokoh pula.
\end{abstract}

Kata kunci: Konselor, Iman, Pribadi Efektif

\section{PENDAHULUAN}

Ada kecenderungan selama ini orang berkeyakinan bahwa konseling yang efektif ditentukan oleh pengguasaan ilmu dan ketrampilan melaksanakan konseling saja, seakan-akan setelah seorang konselor memilki semuanya itu konseling pasti berhasil. Corey (2009 : 18) menyatakan bahwa keberhasilan konseling bukan hanya ditentukan oleh pengetahuan dan ketrampilan yang dimiliki konselor, tetapi karakteristik pribadi menjadi determinan yang paling kuat dalam konseling. hal ini berarti penguasaan ilmu dan ketrampilan konseling belum segalanya, masih ada faktor yang lain yang perlu dipertimbangkan dan dimasukkan dalam kurikulum jurusan Bimbingan dan Konseling pada jenjang S1 dan S2, yaitu Pengembangan Pribadi Konselor agar para calon konselor dan para magister bidang bimbingan memiliki ciriciri kepribadian yang bisa menunjang pelaksanaan konseling.

Lebih jauh Corey menunjukkan beberapa ciri pribadi yang ada kaitannya dengan sukses dalam konseling, yaitu (1) menaruh perhatian pada wajah dunia, yg nampak dari sisi yang menguntungkan konseli, (2) memandang positif pada diri manusia, (3) menaruh kepercayaan pada konseli, (4) menganggap konseli sebagai pribadi yang mampu, (5) bisa dipercaya katakatanya, (6) ramah, (7) memiliki pandangan positif terhadap diri mereka sendiri.

Sejalan dengan karakter pribadi yang dipersyaratkan Corey di atas, hasil survey yang dilakukan oleh mahasiswa progam studi Bimbingan dan Konseling UNNES menunjukan bahwa ada beberapa karakteristik konselor yang menghambat konseli datang kepada konselor, yaitu (1) 
tidak terbuka, (2) terlalu ekslusif untuk mereka yang bermasalah, (3) galak, judes, crewet, cuwek, (4) tidak bisa dipercaya, (5) tidak bisa menyimpan rahasia (6) suka mengancam, (6) meremehkan siswa dan atau orang lain, (7) tempramental/emosional. Sebaliknya sifat-sifat ramah, tidak judes, tidak cuek terhadap siswa, tampilannya selalu rapi dan menarik, jujur dan bisa dipercaya, murah senyum, simpatik, empati, pengertian terhadap konseli, tanggap, tidak membeda-bedakan konseli, dan memiliki ksetabilan emosi diakjui sebagai pendukung siswa mau datang kepada konselor.

Diakui, untu mengembangkan ciri-ciri pribadi yang posistif dan sekaligus menghapus yang negatif tidak bisa dilakukan dengan tiba-tiba, tetapi membutuhkan waktu yang relatif lama, dan proses yang melibatkan banya pihak dan berbagai media. Dalam tulisan ini dipilih "iman" landasan dalam mengembangkan sifat-sifat tersebut, sebab iman ternyata bukan sekedar pengetahuan, lebih dari itu adalah pemberi warna bagi pikiran, perasaan, dan tingkah laku yang mendorong perilaku positif dan sekaligus pengendali sifat-sifat negative. Dengan demikian diharapkan pelaksanaan konseling akan lebih efeltif yang ditandai dengan (1) keefektifan, waktu, biaya dan tenaga, (2) berhasil dan bermanfaat bagi konselor dan konseli, (3) konseli merasa senang karena terlepas dari berbagai kesulitan, sukses mengembangkan diri, dan mencapai cita-cita, dan (4) konselor juga merasa senang karena disayang manusia dan Tuhan.

Penolong seyogianya orang beriman dan bertqawa kepada Allah swt. Beriman kepada Allah artinya meyakini dengan mulut, membenarkan dengan hati, dan mengamalkan apa yang ia yakini itu dalam kehidupan sehari-hari. Orang beriman yakin bahwa Allah itu ada dengan segala sifat-sifat baiknya, Allah memiliki malaikat dengan segala tugasnya, Allah mengutus sejumlah Nabi dan Rasul yang diutus untuk mem-bimbing manusia, Allah memiliki Kitab Suci yang menjadi pedoman hidup manusia, ada taqdir atau ketentuan Allah yang pasti berlaku untuk semua manusia, dan akan datang Hari Kiamat di mana setiap manusia akan diperhitungkan dan dibalas apa yang dilakukan selama hidup di dunia.

Bertaqwa artinya tunduk dan patuh terhadap aturan Allah, yang tampil dalam ketaatan melaksanakan apa-apa yang diajarkan agama. Mengapa penolong perlu beriman dan bertaqwa kepada Allah swt? Ada beberapa fungsi iman dalam kegiatan tolong-menolong yaitu (a) Iman menjadi landasan niat penolong, (b) iman menjadi pembimbing tingkah laku penolong, (c) iman menjadi rujukan dalam memilih cara dan materi menolong, (d) iman yang diikuti dengan taqwa akan menjadikan penolong lebih bermoral dan patut menjadi teladan bagi orang-orang yang ditolong. Keempat kegunaan iman bagi penolong selanjutnya dijelaskan secara singkat berikut : 


\section{PEMBAHASAN}

\section{Iman Menjadi Landasan dan Sekaligus Sandaran dalam Menolong}

Menolong sesama akan bernilai ibadah manakala dilakukan dengan cara-cara Allah swt.artinyasesuai aturan Allah swt.dan diniyatkan untuk mendapatkan ridlo Allah swt. Jika perbuatan menolong itu dilakukan dengan cara-cara Allah dan diniyatkan untuk mencari ridlo Allah, maka pelakunya akan mendapatkan apa yang dijanjikan Allah swt., yaitu "Mendapat pertolongan dari Allah di dunia dan akhirat". Tetapi kalau niyatnya sekedar melaksanakan tugas atau mendapakan materi, bukan untuk mencari ridlo Allah, maka perbuatan menolong itu tidak bisa digolongkan ibadah.Balasannya tentu sesuai yang ia niyatkan.

Pertanyaannya adalah bagaimana mungkin seseorang berbuat karena Allah kalau ia sendiri tidak yakin bahwa Allah itu ada, Allah itu Maha Kuasa atas segala sesuatu? Dalam uangkapan yang berbeda, bagaimana mungkin seseorang bertindak karena atasannya kalau dia sendiri tidak punya atasan, atau tidak yakin bahwa atasannya ada, dan atasan itu punya otoritas untuk menilai kinerjanya serta menentukan pekerja itu bisa naik pangkat atau menduduki posisi tertentu?

Di sisi lain, keimanan kepada Allah me-mungkinkan seorang penolong menyandarkan hasil usahanya kepada Allah. Orang beriman yakin bahwa kesuksesan bukan tergantung sepenuhnya pada hasil usahanya sendiri, tetapi hasil itu sebagian tergantung pada idzin Allah.

Seorang dokter yang beriman pasti tidak berani menyatakan bahwa kesembuhan pasiennya itu tergantung padanya, seorang guru yang beriman tidak akan berani mengatakan bahwa sukses anak didiknya adalah karenya, petani yang beriman pasti tidak berani mengatakan bahwa kesuksesannya dalam bertani adalah karena hasil usahanya sendiri. Dengan keyakinan ini memungkinkan seorang penolong tidak cepat menyombongkan diri ketika berhasil dan tidak mudah putus asa ketika gagal

\section{Iman Menjadi Pembimbing bagi Tingkah Laku Penolong}

Tak bisa dipungkiri bahwa perbuatan menolong berkaitan dengan (1) diri penolong, (2) subyek yang ditolong, dan (3) materi yang diberikan kepada pihak yang ditolong.

Dalam hubungannya dengan diri penolong sendiri, penolong juga manusia yang tidak luput dari perbuatan salah dan dosa. Dengan iman yang benar memungkinkan iman itu bisa membimbing penolong menuju perilaku yang lebih baik dan terpuji, serta layak diteladani oleh individu yang ditolong. Sebab menolong orang ternyata bukan sekedar apa yang diucapkan atau diberikan oleh penolong, tetapi lebih dari itu adalah apa yang dilakukan penolong dalam kehidupan sehari-hari.

Jika perilaku penolong tidak terpuji bisa jadi menjadi penghalang bantuan yang akan diberikan oleh penolong kepada pihak yang ditolong. Sebagai pembanding, buatlah "es buah" 
yang enak dan lengkap, kemudian tuangkan dalam pis-pot atau gelas kotor selanjutnya berikan kepada orang di sekitar anda, bagaimana reaksinya? Hampir pasti es buah itu menjadi tidak enak diminum lantaran wadahnya menjijikkan, kalau ada orang yang mau minum adalah karena terpaksa.

Di samping itu, dengan iman yang benar, ada "tempat bersandar" bagi penolong dalam menyerahkan hasil usahanya. Sehebat apapun seorang dokter, tentu ia tidak berani menjamin $100 \%$ keberhasilan tindakannya dalam menolong pasien; sehebat apapun seorang guru, ia juga tidak akan berani menjamin 100\% keberhasilan pendidikan yang ia lakukan, meskipun terhadap anak kandungnya sendiri, demikian pula pada profesi yang lain. Oleh sebab itu penolong perlu memiliki tempat menyandarkan hasil usahanya agar berhasil, yaitu kepada Tuhan yang diimaninya.

Iman juga memungkinkan seorang penolong menjadi lebih ikhlas dan bersabar, sebab penolong yang beriman yakin bahwa dalam setiap kebaikan yang ia lakukan pasti ada balasan dari Allah swt. jika ia lakukan dengan ikhlas, artinya apa yang ia lakukan hanya semata-mata mengharapkan ridlo Allah swt.,

Dengan iman juga memungkinkan penolong yang beriman akan menjadi sabar, sebab orang yang beriman yakin bahwa ada ketentuan Allah (takdir) yang pasti berlaku untuk semua manusia. Oleh sebab itu bila sukses ia tidak menyombongkan diri, dan bila gagal ia bersabar.

Seorang filosof tekenal Immanuel Kant menyatakan: "Seujung rambut pun saya tidak bisa lepas dari ketentuan Tuhan”. Perhatikanlah, apakah semua dokter sukses menolong pasiennya? Ternyata ada satu atau dua pasien yang tidak berhasil ditolong oleh seorang atau tim dokter meskipun mereka semuanya ahli.

Dalam kaitannya dengan subyek yang ditolong utamanya adalah manusia, ia mempunyai pikiran, perasaan, dan juga iman. Penolong dalam menolong seseorang seyogianya mempertimbangkan aspek keimanan individu yang ditolong, baik dalam tindakan, ucapan, maupun materi dan rujukan yang diberikan.

Penolong sebaiknya memilih tindakan yang lebih sesuai dengan agama yang dianut oleh subyek yang ditolong. Misal datang ke masyarakat muslim dengan tampilan yang tidak sesuai dengan tuntunan agama, pada saat orang-orang sedang beribadah, dan atau membawa materi yang itu dilarang oleh agama. Tindakan semacam itu tentu akan mengurangi keberhsilan pertolongan yang diberikan.

Dalam kaitannya dengan materi yang harus diberikan kepada pihak yang ditolong, diakui bahwa kegiatan menolong hampir tidak bisa dipisahkan dengan materi, artinya dalam kegiatan menolong hampir selalu diperlukan materi, dan bisa jadi materi itu harus dikeluarkan dari miliknya sendiri. 
Penolong yang memiliki keimanan yang kuat, ia yakin bahwa harta yang ia keluarkan untuk mem-bantu orang lain tidak pernah hilang percuma, tetapi pada saatnya pasti akan dikembalikan oleh Allah dan bisa jadi dalam jumlah yang lebih banyak.

Di samping itu pemberian kepada orang lain (sodaqoh) diyakini bisa menhindarkan pelakunya dari bencana. Oleh sebab itu, orang beriman yang meyakini hikmah di balik sodaqoh akan menjadi lebih ringan mengeluarkan hartanya untuk membantu orang lain yang membutuhkan.

Diakui bahwa dalam beberpa kasus dijumpai orang-orang yang kelihatannya imannya kuat tetapi masih menyembunyikan barang bantuan atau menahan diri dari membantu orang lain. Hal ini dimungkinkan karena (1) kurang percayanya kepada pihak yang dibantu, bukankah di sana-sini banyak kita jumpai orang yang berkedok kesusahan hanya untuk menarik simpati orang, (2) kecintaan yang berlebih terhadap harta, yang menyebabkan ia buta dan gila harta, (3) kemiskinan yang menyebabkan ia mudah dirayu oleh syetan, dan (4) lemahnya kontrol diri dan juga lingkungan yang menyebabkan pemegang barang/uang bantuan terdorong untuk menyelewengkan.

\section{Iman Menjadi Rujukan dalam Memilih Cara dan Materi Menolong}

Menolong orang bukan hanya masalah "cara" atau "teknik"menolong, tetapi juga "apa" yang akan diberikan kepada pihak yang ditolong. Istilah "apa" di sini berkenaan dengan sesuatu yang diberikan kepada pihak yang ditolong adalah sesuatu yang benar dan baik untuk pihak yang ditolong, baik sesuatu itu berkaitan dengan pemikiran, tindakan, kata-kata, atau materi yang disampikan kepada subyek yang ditolong.

Diakui bahwa untuk mendapatkan pemikiran yang benar tidak cukup hanya mendasarkan pada hasil pemikiran dan ilmu pengetahuan semata, tetapi dalam beberapa kasus perlu pula didekati dengan cara agama, sebab pikiran dan ilmu pengetahuan tidak selalu mampu menjangkau semua persoalan yang dihadapi manusia.

Dalam kasus kehilangan orang yang sangat dicintai, penyakit yang tidakkunjung sembuh, bencana alam dan sebagainya adalah peristiwa-peristiwa yang tidak dapat dijelaskan secara mudah dengan akal manusia. Oleh sebab itu penolong sebaik-nya memiliki keimanan yang kuat dan mentaatinya. Dengan keimanan itu memungkinkan penolong mencari jalan keluar melalui cara agama di samping melalui cara akal dan ilmu.

Iman yang didalamnya terkandung iman kepada Kitab Allah, di dalam kitab suci itu terdapat sejumlah cara untuk mengatasi persoalan yang dihadapi manusia, yang tidak terjawab melalui pengetahuan ilmiah. Misal rujukan untuk membantu keluarga yang lama tidak dikaruniai keturunan (QS, $71: 10-12)$, menolong orang yang mengalami kegagalan berat yang bisa menyebabkan stress (QS, 61 : 2-3), jaminan akan ada pertolongan Allah dan jalan keluar 
dari setiap kesulitan yang dihadapi bagi orang-orang yang bertaqwa (QS, 16 : 97), jaminan akan mendapatkan kehidupan yang baik bagi orang yang beriman dan beramal sholih (QS, 9 : 129), jaminan akan mendapatkan penyelesaian yang terbaik dari kesusahan yang dihadapi individu (QS : 50 : 17-18).

Keimanan kepada malaikat memungkinkan seorang penolong yakin bahwa ada dua malikat Allah yang selalu mencatat segala tingkah lakunya (QS, $13: 11$ ), oleh sebab itu ia tidak berani bertindak sembarangan. Orang yang beriman kepada malaikat memungkinkan tidak mudah takut menghadapi hal-hal yang orang lain takut, karena ia tahu bahwa kemanapun ia pergi selalu dikawal oleh dua malaikat yang selalu mengikutinya scara bergiliran di depan dan belakangnya, mereka menjaganya atas perintah Allah.

Keimanan kepada takdir Allah memungkinkah seorang penolong menjadikan rujukan dalam menolong, bahwa seseorang tidak bisa menggantung-kan hasil usahanya kepada dirinya sendiri, sebaliknya orang yang beriman yakin bahwa ada takdir Allah yang pasti berlaku untuk semua manusia. Oleh sebab itu meski ia berupaya maksimal dan didukung dengan pengetahuan serta peralatan yang serba canggih, ia tetap perlu menyandarkan hasil akhirnya kepada Allah. Dengan demikian penolong tidak mudah bangga jika berhasil, dan tidak mudah putus asa ketika gagal.

Keimanan kepada hari pembalasan me-mungkinkan penolong bisa mayakinkan pihak yang ditolong, bahwa hidup bukan hanya di sini dan saat ini saja, masih akan ada kehidupan yang abadi yaitu hari pembalasan. Orang yang teraniaya di dunia dan belum sempat terbalaskan, akan dibalas pada hari pembalsan.Demikian pula perbuatan baik yang belum mendapatkan balasan di dunia juga dibalas berlipat di akhirat.

\section{PENUTUP}

Sebagai bahan renungan, penolong yang beriman dan bertaqwa layak menjadi teladan bagi pihak yang ditolong, sehingga memungkinkan bantuan yang diberikan menjadi lebih efektif. Diakui bahwa dalam menolong orang, keteladanan dari pihak penolong adalah sangat penting. Pepatah Ingris mengatakan, "A good example is the best sermon" (Contoh yang baik adalah nasehat yang baik).

Penolong yang beriman takut kalau dia hanya bisa menasihati tetapi tidak mampu melaksanakan apa yang dinasehatkan. Sebab bagi orang berbicara tetapi tidak sesuai dengan tingkah lakunya tergolong orang yang dibenci oleh Allah swt (QS, 61 : 3). Penolong juga manusia biasa, bisa jadi ia berhasil menolong orang lain tetapi tidak berhasil menolong diri sendiri.

Penolong yang beriman yakin bahwa selama jalan yang ditempuh sudah sesuai dengan jalan yang ditunjukkan Allah, janji Allah pasti akan datang, Allah tak pernah mengingkari janji- 
Nya. Allah Maha Mengetahui apa yang terbaik bagi hamba-Nya, dan kapan waktu yang paling tepat do'a seseorang dikabulkan. Keyakinan itu yang membuat penolong yang beriman selalu tenang dan optimis dalam menghadapi berbagai persoalan.

Tetapi bagaimana jika penolong tidak mengenal Tuhan? Kalau sukses ia menyombongkan diri, kalau gagal ia mudah putus asa. Terkadang perilakunya tidak terkontrol, menghalalkan segala macam cara untuk mendapatkan keuntungan pribadi, yang tidak jarang mengantarkannya masuk bui, perhatikan pula kasus penyelahgunaan dana bantuan sosial, yang akhirnya mengantarkan beberpa orang masuk penjara.

\section{DAFTAR PUSTAKA}

Al-Quran dan Terjemahnya. (2006). Wakaf dari Pelayan Dua Tanah Suci Raja Abdullah bin Abdul Aziz ali Sa'ud. Kerajaan Arab Saudi.

Antonio, S. M.. (2014). The Greatest Inspirator \& Motivator. Jakarta : Tazkia Publishing

Corey, G (2009). Theory and Practice of Counseling and Psychotherapy. New York : Brppks/ColePublishing Company

Hamka, (2008). Tafsir al-Azhar jilid I. Jakarta : Pustaka Panjimas

Katsir, I. (2000), Ringkasan Tafsir Ibnu Katsir IV (Alih bahasa: Syihabuddin) Jakarta: Gema Insani Press

Shihab, M.Q. (2000). Tafsir Al-Misbah Jilid I. Jakarta : Lentera Hati

Shihab, M.Q. (2002). Tafsir Al-Misbah Jilid VI. Jakarta : Lentera Hati 